\title{
Effects of Oxidation-Reduction Potentials on Soil Microbes
}

\author{
Gabriel Olufemi DAYO-OLAGBENDE*, Solomon Alaba ADEJORO, Babatunde Sunday EWULO, \\ Moses Adeyemi AWODUN \\ Department of Crop, Soil and Pest Management, Federal University of Technology Akure, PMB 704, Nigeria
}

\begin{abstract}
Soil microbes are important in various processes that lead to soil fertility, nutrient availability and plant nutrition. These soil microbial organisms are themselves affected by the environment where they occur. Microbes could either be aerobic or anaerobic depending on their oxygen requirements. Oxidation-reduction reaction is a common reaction in anoxic environments and microbes tend to respond to it in different ways. This study therefore sets out to investigate the effect of oxidation-reduction potentials of the soil on activities of soil microorganisms. Results from this study show that highly reduced soils favors bacteria population more than fungi. It was concluded that the survival of fungi is best supported under oxidized and moderately reduced soils, but their existence can be negatively affected when soils become highly reduced. Bacteria that are aerobic thrive best under oxidized and moderately reduced soil. In these conditions, the highest microbial respiration in the soil was also measured.
\end{abstract}

Key words: bacteria, fungi, population, respiration, redox potential

\section{INTRODUCTION}

The soil houses a large portion of the world's biodiversity and microbes constituting a vast majority of this biodiversity (Menta, 2012). Though the links between soil organisms and functionality are very complex, soil organisms are still considered very important in ecosystems because they affect physical properties and processes like binding together soil particles into aggregates. They also contribute to carbon and energy fluxes, cycling of nutrients as well as soil reactions (Johns, 2017; Kannojia et al., 2019). The chemistry of soil reactions like redox potential $(\mathrm{Eh})$ is regulated by catalytic enzymes that are secreted by soil microbes (Fenchel et al., 2012); so also microbial activities depend on the soil reaction and redox potential (Falkowski et al., 2008). Redox potential has been suggested for characterization of microbial groups, since each type adapted to specific oxido-reducing conditions in either a wide or narrow redox-potential range. Redox potential has an effect on the development of microorganisms. Bacterial growth has been found to be directly correlated to changes in redox potential (Kimbrough et al., 2006). So also, microbial and enzymatic activities are negatively correlated with redox potential in anaerobic soils (Brzezinska, 2004; Kralova et al., 1992). Furthermore, the redox state of nodules is regarded as a referee of legume-rhizobium symbiosis (Marino et al., 2009). The constituents of living organisms particularly proteins are just six elements: oxygen - the strongest oxidizing agent, hydrogen - the strongest reducing agent; and four elements that have the largest amplitude in redox numbers: carbon ( $-\mathrm{IV}$ in $\mathrm{CH}_{4}$ to $+\mathrm{IV}$ in $\mathrm{CO}_{2}$ ), nitrogen (-III in $\mathrm{NH}_{4}$ to $+\mathrm{V}$ in $\mathrm{NO}_{3}^{-}$), phosphorus (-III in $\mathrm{PH}_{3}$ to $+\mathrm{V}$ in $\mathrm{PO}_{4}^{3-}$ ), and sulfur (-II in $\mathrm{H}_{2} \mathrm{~S}$ to $+\mathrm{VI}$ in $\mathrm{SO}_{4}^{2-}$ ). In the process of photosynthesis, plants use light energy to reduce carbon dioxide from the air with hydrogen taken from water (Govindjee and Krogmann, 2004). This reaction produces glucose and releases oxygen. Consequently, the redox state is a critical determinant of the functioning of the cell, and any major imbalances can cause severe damage or death to plants (Dietz and Scheibe, 2004). However, compared with other organisms, soil microorganisms exhibit greater 
capability of modifying the redox potential and $\mathrm{pH}$ of their environment to meet their requirements (Fierer and Jackson, 2006), they can also break down organic matter, making nutrients available for uptake by plants and other organisms and in the process serve as electron shuttle particularly under waterlogged conditions. Decomposition in itself is an oxidation process and is controlled by the interactions of the physical environment and external factors that control the survival and functionality of microbes (Prescott, 2010). The role of the oxidation-reduction potential in determination of the availability of substrates in the surface environment and its essential role in regulation of the abundance and species diversity of microbial communities have been explored by many other authors (Lüdemann et al., 2000, Pett-Ridge and Firestone 2005, Hines et al., 2006). However, updated information is required on the effect of oxidation-reduction status of soil on soil microbes. Hence the objective of this study is to evaluate the effect of redox potential on soil microbial activities.

\section{MATERIALS AND METHODS}

The study was conducted using two sandy clay loam soils with different percentages of size fractions. The site of the experiment was at Apatapiti layout around the west gate of Federal University of Technology, Akure (FUTA) Ondo State Nigeria. It lies within the tropical rainforest belt in southwestern Nigeria within latitude $5^{\circ} 16^{l} \mathrm{~N}-5^{\circ} 22^{\mathrm{l}} \mathrm{N}$ and longitude $15^{\circ} 11^{1} \mathrm{E}-15^{\circ} 16^{1} \mathrm{E}$. An average annual temperature of the location ranged from 21.8 to $32.3{ }^{\circ} \mathrm{C}$. Annual rainfall varied from 1.900 to $2.700 \mathrm{~mm}$, with mean annual evaporation of $2.1 \mathrm{~mm}$. The relative humidity ranged between $85 \%$ during the rainy season and less than $60 \%$ during the dry season. The soil according to FAO soil classification is a Nitisol or Alfisol according to USDA classification (FAO, 2006; WRBSR, 2014).

\section{Experimental design and treatments combination:}

A $3 \times 2 \times 2$ factorial experiment was set up on two sandy clay loam soils, arranged in a completely randomized design and replicated three times. The treatments combination involved three levels of poultry manure $\left(0\right.$ t.ha $^{-1}, 6$ t.ha $^{-1}$ and 8 t.ha $\left.{ }^{-1}\right)$, two levels of NPK 15-15-15 $\left(0\right.$ kg.ha- $\left.{ }^{-1}, 200 \mathrm{~kg}^{-h^{-1}}\right)$ and two watering regimes (field capacity and waterlogging). A total of twelve treatments were obtained with different redox potential (Eh): oxidized soils (Eh $>300 \mathrm{mV}$ ), moderately reduced soil (Eh range 100 to $300 \mathrm{mV}$ ), reduced soil (Eh range -100 to $100 \mathrm{mV})$ and highly reduced $(\mathrm{Eh}<-100 \mathrm{mV})$.

\section{Soil analysis and sampling}

Samples of the soil were randomly collected from the experimental site at a depth of $0-15 \mathrm{~cm}$. The collected samples were analyzed for redox potential and microbial activities from 1 week to 12 weeks after incubation at an interval of 4 weeks (1WAI, 4WAI 8WAI and 12WAI). For analysis of redox potential, a method similar to that described by Rabenhorst et al. (2009) was used. In short, $20 \mathrm{~g}$ of the soil samples were collected, soaked in distilled water from bottom to top so as to prevent entrapment of air during saturation and allowed to mix for $30 \mathrm{~min}$ after which $50 \mathrm{ml}$ of the solution was collected and taken to the laboratory for reading. In the laboratory, redox potential was measured using a $\mathrm{pH} /$ Redox combined meter. Voltage was measured every $10 \mathrm{~s}$ for $60 \mathrm{~s}$ and the mean values of the collected measurements were calculated.

Soil microbial population was carried out using the colony count method. Soil samples were collected and stored in a sterile container for cultivatable fungal and bacterial analysis. Serial dilutions (up to $10^{-5}$ ) were prepared and $1 \mathrm{ml}$ from each dilution was dispensed on nutrient agar for the culture of bacterial while potato dextrose agar was used for fungal culture. Bacteria culture was done according to the description given by Paul and Clark (1989). Inoculated plates were incubated at $25^{\circ} \mathrm{C}$ for 48 hours after which the colony formed were counted. Culture of fungi was done following the procedure of Harrigan and McCance (1976). The inoculated plates were incubated for 5 days at a temperature of $28^{\circ} \mathrm{C}$ and total number of fungi was counted. Number of colony for each dilution was counted and the amount of bacteria and fungi were calculated by using the following equation:

$\mathrm{CFU} / \mathrm{ml}=$ (number of colonies $\times$ dilution factor) $/$ (volume of cultured plate)

Gas entrapment method was used to determine the microbial respiration of the soil samples in this study. $10 \mathrm{ml}$ of $0.5 \mathrm{M} \mathrm{NaOH}$ was dispensed into a beaker and placed on the top of $50 \mathrm{~g}$ soil inside a plastic jar to trap $\mathrm{CO}_{2}$ evolved from the soil. A separate jar without soil was used as a control which also contained $10 \mathrm{ml}$ of $0.5 \mathrm{M} \mathrm{NaOH}$ to account for $\mathrm{CO}_{2}$ trapped from the atmosphere. After 24 hours, the $\mathrm{NaOH}$ was gently removed, covered with an aluminum foil and immediately passed on for $\mathrm{CO}_{2}$ determination. $1 \mathrm{M} \mathrm{BaCl}_{2}$ was added to the $\mathrm{NaOH}$ beaker to precipitate the carbonates to facilitate determination of $\mathrm{CO}_{2}$ evolved from the soil after which the evolved $\mathrm{CO}_{2}$ was determined by titration. Excess $\mathrm{NaOH}$ was titrated against $0.5 \mathrm{M} \mathrm{HCl}$ using phenolphthalein as indicator after precipitating the carbonate formed with $1.0 \mathrm{M} \mathrm{BaCl}_{2}$. The solution goes from pink to white and then colorless which represents the end point. $\mathrm{CO}_{2}$ was then calculated using the following formula:

$\mathrm{CO}_{2}=(\mathrm{B} \times \mathrm{V}) \times(\mathrm{N} \times \mathrm{E})$

where:

$\mathrm{B}=$ blank (reading of the $\mathrm{CO}_{2}$ trapped from the atmosphere $\left.\left(\mathrm{mol}^{-1}\right)\right)$

$\mathrm{V}=$ volume of acid (final value - initial value $(\mathrm{mol} / \mathrm{L})$ )

$\mathrm{N}=$ normality of acid (meq/L)

$\mathrm{E}=$ equivalent weight of $\mathrm{C}$ in $\mathrm{CO}_{2}(\mathrm{~g})$

\section{Data Analysis}

Data obtained from this study were subjected to analysis of variance (ANOVA) using statistical package SPSS version 17, 
while means where separated using Tukey Range test. Figures were generated using MS excel 2010 to show the trends of findings.

\section{RESULTS}

Table 1 presents the pre-experiment analysis of soils; the $\mathrm{pH}$ was measured in water. Soil 1 was a slightly acidic $(\mathrm{pH}$ $=6.26$ ) sandy clay loam, having a sand content of $54.8 \%$, silt of $20.5 \%$ and clay of $24.7 \%$. Its redox potential was $260 \mathrm{mV}$ making it a moderately reduced soil, bacteria population of $3.70 \times 10^{-5}$ cfu. $\mathrm{ml}^{-1}$ and fungi population of $2.66 \times 10^{-5} \mathrm{cfu} . \mathrm{ml}^{-1}$. Soil 2 was a slightly alkaline $(\mathrm{pH}=8.25)$ clay loam having a sand content of $48.0 \%$, silt content of $21.4 \%$ and clay content of $30.6 \%$. It was also a moderately reduced soil with Eh of 282 $\mathrm{mV}$. Bacteria population of soil 2 was $4.76 \times 10^{-5} \mathrm{cfu}^{-\mathrm{ml}^{-1}}$ and fungi population of $3.41 \times 10^{-5} \mathrm{cfu}^{\mathrm{m} \mathrm{m}^{-1}}$. Generally, the two soils are considered moderately fertile.

\section{Table 1: Pre-experimental soil analysis}

\begin{tabular}{|c|c|c|}
\hline Properties & Soil 1 & Soil 2 \\
\hline $\begin{array}{l}\text { Redox potential } \\
(\mathrm{mV})\end{array}$ & 260 & 282 \\
\hline pH (water) & 6.26 & 8.25 \\
\hline Sand \% & 54.8 & 48.0 \\
\hline Silt \% & 20.5 & 21.4 \\
\hline Clay \% & 24.7 & 30.6 \\
\hline Textural class & $\begin{array}{l}\text { Sandy clay } \\
\text { loam }\end{array}$ & Sandy clay loam \\
\hline $\begin{array}{l}\text { Bacteria population } \\
\left(\mathrm{cfu} . \mathrm{ml}^{-1}\right)\end{array}$ & $3.90 \times 10^{-5}$ & $4.76 \times 10^{-5}$ \\
\hline $\begin{array}{l}\text { Fungi population } \\
\left(\mathrm{cfu} \cdot \mathrm{ml}^{-1}\right)\end{array}$ & $2.66 \times 10^{-5}$ & $3.41 \times 10^{-5}$ \\
\hline $\begin{array}{l}\text { Microbial } \\
\text { respiration (mg } \\
\left.\mathrm{CO}_{2}-\mathrm{C} \mathrm{g}^{-1} \mathrm{~h}^{-1}\right)\end{array}$ & 13.5 & 15.6 \\
\hline Organic matter \% & 1.60 & 2.36 \\
\hline $\mathrm{N} \%$ & 0.19 & 0.17 \\
\hline $\mathrm{P}(\mathrm{ppm})$ & 15.2 & 24.8 \\
\hline $\mathrm{K}\left(\mathrm{cmol} . \mathrm{kg}^{-1}\right)$ & 0.16 & 0.18 \\
\hline
\end{tabular}

Table 2: Classification of treatment based on redox potential (Eh) range

\begin{tabular}{|l|l|l|l|}
\hline Treatments & Treatment description & Eh range $(\mathrm{mV})$ & Eh class \\
\hline $\mathrm{T}_{1}$ & $0 \mathrm{t} \mathrm{ha}^{-1} \mathrm{PM}+0 \mathrm{~kg} \mathrm{ha}^{-1} \mathrm{NPK}+\mathrm{FC}$ & 200 to 370 & Oxidized \\
\hline $\mathrm{T}_{2}$ & $0 \mathrm{tha}^{-1} \mathrm{PM}+0 \mathrm{~kg} \mathrm{ha}^{-1} \mathrm{NPK}+\mathrm{WL}$ & -120 to -100 & Reduced \\
\hline $\mathrm{T}_{3}$ & $0 \mathrm{t} \mathrm{ha}^{-1} \mathrm{PM}+200 \mathrm{~kg} \mathrm{ha}^{-1} \mathrm{NPK}+\mathrm{FC}$ & 260 to 430 & Oxidized \\
\hline $\mathrm{T}_{4}$ & $0 \mathrm{t} \mathrm{ha}^{-1} \mathrm{PM}+200 \mathrm{kgha}^{-1} \mathrm{NPK}+\mathrm{WL}$ & -130 to -100 & Reduced \\
\hline $\mathrm{T}_{5}$ & $6 \mathrm{t} \mathrm{ha}^{-1} \mathrm{PM}+0 \mathrm{~kg} \mathrm{ha}^{-1} \mathrm{NPK}+\mathrm{FC}$ & 200 to 290 & Moderately reduced \\
\hline $\mathrm{T}_{6}$ & $6 \mathrm{t} \mathrm{ha}^{-1} \mathrm{PM}+0 \mathrm{~kg} \mathrm{ha}^{-1} \mathrm{NPK}+\mathrm{WL}$ & -240 to -210 & Highly reduced \\
\hline $\mathrm{T}_{7}$ & $6 \mathrm{tha}^{-1} \mathrm{PM}+200 \mathrm{~kg} \mathrm{ha}^{-1} \mathrm{NPK}+\mathrm{FC}$ & 280 to 310 & Oxidized \\
\hline $\mathrm{T}_{8}$ & $6 \mathrm{tha}^{-1} \mathrm{PM}+200 \mathrm{~kg} \mathrm{ha}^{-1} \mathrm{NPK}+\mathrm{WL}$ & -230 to -200 & Highly reduced \\
\hline $\mathrm{T}_{9}$ & $8 \mathrm{tha}^{-1} \mathrm{PM}+0 \mathrm{~kg} \mathrm{ha}^{-1} \mathrm{NPK}+\mathrm{FC}$ & 230 to 300 & Moderately reduced \\
\hline $\mathrm{T}_{10}$ & $8 \mathrm{tha}^{-1} \mathrm{PM}+0 \mathrm{~kg} \mathrm{ha}^{-1} \mathrm{NPK}+\mathrm{WL}$ & -240 to -230 & Highly reduced \\
\hline $\mathrm{T}_{11}$ & $8 \mathrm{tha}^{-1} \mathrm{PM}+200 \mathrm{~kg} \mathrm{ha}^{-1} \mathrm{NPK}+\mathrm{FC}$ & 230 to 300 & Moderately reduced \\
\hline $\mathrm{T}_{12}$ & $8 \mathrm{tha}^{-1} \mathrm{PM}+200 \mathrm{~kg} \mathrm{ha}^{-1} \mathrm{NPK}+\mathrm{WL}$ & -240 to -230 & Highly reduced \\
\hline
\end{tabular}

PM - Poultry manure, NPK - NPK 15-15-15, WL - Waterlogged, FC - Field capacity, Eh - redox potential
Table 2 shows the classification of treatments based on redox potential (Eh) values. T1 (200 to $370 \mathrm{mV})$, T3 (260 to $430 \mathrm{mV}$ ) and T7 (280 to $310 \mathrm{mV}$ ) fell into oxidized soil (Eh $>300 \mathrm{mV})$, T5 (200 to $290 \mathrm{mV}$ ), T9 (230 to $300 \mathrm{mV}$ ) and $\mathrm{T} 11$ (230 to $300 \mathrm{mV}$ ) were moderately reduced $(100 \mathrm{mV}$ to $300 \mathrm{mV}), \mathrm{T} 2(-120$ to $-100 \mathrm{mV})$ and $\mathrm{T} 4(-130$ to -100$)$ were reduced soils $(-100 \mathrm{mV}$ to $100 \mathrm{mV})$ and $\mathrm{T} 6(-240$ to -210 $\mathrm{mV})$, T8 (-230 to $-200 \mathrm{mV}), \mathrm{T} 10(-240$ to $-230 \mathrm{mV})$ and $\mathrm{T} 12$ $(-240$ to $-230 \mathrm{mV})$ were highly reduced soils $(<-100 \mathrm{mV})$.

Table 3 presents the effect of redox potential on soil biological properties (bacteria population, fungi population, basal and substrate induced respiration) at 12 weeks after incubation (WAI). On soil 1, highly reduced soils and moderately reduced soils $\left\{\mathrm{T} 12\left(4.31 \times 10^{-5} \mathrm{cfu}^{\mathrm{m} l^{-1}}\right), \mathrm{T} 11\right.$ $\left(4.08 \times 10^{-5}\right.$ cfu.ml $\left.{ }^{-1}\right)$, T9 $\left(4.08 \times 10^{-5}\right.$ cfu. ml $\left.^{-1}\right)$, T8 $\left(4.29 \times 10^{-5}\right.$ cfu.ml $\left.{ }^{-1}\right)$, T7 $\left(4.03 \times 10^{-5}\right.$ cfu.ml $\left.^{-1}\right)$ and T6 $\left(4.04 \times 10^{-5} \mathrm{cfu}\right.$. $\left.\left.\mathrm{ml}^{-1}\right)\right\}$ recorded the highest bacteria population, however no significant difference was observed among them. The lowest bacteria population was observed on T1 $\left(2.87 \times 10^{-5}\right.$ cfu.ml $\left.{ }^{-1}\right)$, T2 $\left(2.67 \times 10^{-5}\right.$ cfu.ml $\left.{ }^{-1}\right)$ and T4 $\left(2.32 \times 10^{-5}\right.$ cfu.ml $\left.{ }^{-1}\right)$ (oxidized soil and reduced soil). Fungi population was the highest on moderately reduced soil T11 $\left(4.22 \times 10^{-5} \mathrm{cfu}^{\mathrm{m} \mathrm{m}^{-1}}\right)$ and the lowest on highly reduced soil T12 $\left(2.54 \times 10^{-5} \mathrm{cfu}\right.$. $\left.\mathrm{ml}^{-1}\right)$. $\mathrm{CO}_{2}$ content for basal respiration was the highest on

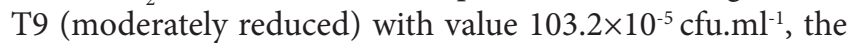
lowest on T1 (oxidized) with value $13.7 \times 10^{-5} \mathrm{cfu}^{-\mathrm{ml}^{-1}}$, while substrate induced respiration was highest on T5 (moderately reduced) with value $34.8 \times 10^{-5} \mathrm{cfu} . \mathrm{ml}^{-1}$ and lowest on $\mathrm{T} 1$ (oxidized) with value $12.0 \times 10^{-5} \mathrm{cfu}^{\mathrm{m} \mathrm{m}^{-1}}$. The same trend was observed in soil 2.

Figures 1 and 2 presents the microbial population trend of bacteria and fungi, respectively. Figures show the trend of the microbial population over incubation time as affected by the redox potentials. In all, there are four redox potentials and the four are represented in the graph. The twelve treatments fall into one of the redox potential represented on the graph.

Figure 1 shows the bacteria population trend from 1WAI to 12WAI for the two soils used for the trials. Black line represents soils that were subjected to highly reduced conditions, red line represents reduced soils, green represents moderately reduced and blue represents oxidized soils. Similar trend 
Table 3: Effect of redox potential on biological properties of soil

\begin{tabular}{|c|c|c|c|c|c|c|c|c|}
\hline \multirow{3}{*}{ Treatments } & \multicolumn{4}{|c|}{ Soil 1} & \multicolumn{4}{|c|}{ Soil 2} \\
\hline & Bacteria & Fungi & $\mathrm{BR}$ & SIR & Bacteria & Fungi & $\mathrm{BR}$ & SIR \\
\hline & \multicolumn{2}{|c|}{ cfu $\mathrm{ml}^{-1}$ soil $\times 10^{-5}$} & \multicolumn{2}{|c|}{$\mathrm{mg} \mathrm{CO}_{2}-\mathrm{C} \mathrm{g}^{-1} \mathrm{~h}^{-1}$} & \multicolumn{2}{|c|}{ cfu ml ${ }^{-1}$ soil $\times 10^{-5}$} & \multicolumn{2}{|c|}{$\mathrm{mg} \mathrm{CO}_{2}-\mathrm{Cg}^{-1} \mathrm{~h}^{-1}$} \\
\hline $\mathrm{T}_{1}$ & $2.87 c$ & $3.49 \mathrm{ab}$ & $13.7 \mathrm{i}$ & $12.0 \mathrm{~g}$ & $1.42 \mathrm{e}$ & $3.90 \mathrm{abc}$ & $42.6 \mathrm{~g}$ & $10.2 \mathrm{~g}$ \\
\hline $\mathrm{T}_{2}$ & $2.67 c$ & $3.40 \mathrm{~b}$ & $7.80 \mathrm{j}$ & $15.0 \mathrm{f}$ & $1.66 \mathrm{e}$ & $3.41 \mathrm{c}$ & $31.8 \mathrm{~h}$ & $12.6 \mathrm{f}$ \\
\hline $\mathrm{T}_{3}$ & $3.86 \mathrm{~b}$ & $4.14 \mathrm{ab}$ & $74.6 \mathrm{f}$ & $32.4 \mathrm{~b}$ & $4.21 \mathrm{abc}$ & $4.70 \mathrm{a}$ & $64.6 \mathrm{e}$ & $27.2 \mathrm{c}$ \\
\hline $\mathrm{T}_{4}$ & $2.32 \mathrm{c}$ & $3.40 \mathrm{~b}$ & $28.8 \mathrm{~h}$ & $26.4 \mathrm{~d}$ & $1.57 \mathrm{e}$ & $3.54 \mathrm{bc}$ & $61.0 \mathrm{f}$ & $22.7 \mathrm{e}$ \\
\hline $\mathrm{T}_{5}$ & $3.74 \mathrm{~b}$ & $3.45 \mathrm{ab}$ & $76.8 \mathrm{e}$ & $34.8 \mathrm{a}$ & $4.43 \mathrm{ab}$ & $4.04 \mathrm{abc}$ & $73.6 \mathrm{c}$ & $27.7 \mathrm{c}$ \\
\hline $\mathrm{T}_{6}$ & $4.04 \mathrm{a}$ & $1.65 \mathrm{~d}$ & $54.4 \mathrm{~g}$ & $30.6 c$ & $3.63 \mathrm{bcd}$ & $1.11 \mathrm{e}$ & $65.9 \mathrm{e}$ & $25.4 \mathrm{~d}$ \\
\hline $\mathrm{T}_{7}$ & $4.03 \mathrm{a}$ & $3.61 \mathrm{ab}$ & $81.6 \mathrm{c}$ & $34.2 \mathrm{a}$ & $3.49 \mathrm{~cd}$ & $4.19 \mathrm{abc}$ & $75.6 \mathrm{~b}$ & $32.1 \mathrm{a}$ \\
\hline $\mathrm{T}_{8}$ & $4.29 a$ & $2.43 \mathrm{~cd}$ & $78.0 \mathrm{~d}$ & $23.4 \mathrm{e}$ & $3.93 a-d$ & $1.41 \mathrm{e}$ & $76.1 \mathrm{~b}$ & $29.2 \mathrm{~b}$ \\
\hline $\mathrm{T}_{9}$ & $4.08 \mathrm{a}$ & $3.89 \mathrm{ab}$ & $103.2 \mathrm{a}$ & $32.4 \mathrm{~b}$ & $3.32 \mathrm{~d}$ & $4.13 \mathrm{abc}$ & $105.8 \mathrm{a}$ & $31.8 \mathrm{a}$ \\
\hline $\mathrm{T}_{10}$ & $3.85 b$ & $2.35 \mathrm{~cd}$ & $76.8 \mathrm{e}$ & $12.0 \mathrm{~g}$ & $3.82 \mathrm{bcd}$ & $2.45 \mathrm{~d}$ & $73.1 \mathrm{c}$ & $28.9 b$ \\
\hline $\mathrm{T}_{11}$ & $4.08 \mathrm{a}$ & $4.22 \mathrm{a}$ & $89.4 \mathrm{~b}$ & $10.2 \mathrm{~h}$ & $3.88 \mathrm{a}-\mathrm{d}$ & $4.33 \mathrm{ab}$ & $76.2 \mathrm{~b}$ & $29.4 \mathrm{~b}$ \\
\hline $\mathrm{T}_{12}$ & $4.31 \mathrm{a}$ & $2.54 \mathrm{c}$ & $76.8 \mathrm{e}$ & $25.8 \mathrm{~d}$ & $4.71 \mathrm{a}$ & $1.81 \mathrm{de}$ & $70.3 \mathrm{~d}$ & $12.6 \mathrm{f}$ \\
\hline
\end{tabular}

Means followed by the same letters are not significantly $(\mathrm{p}>0.05)$ different according to Tukey HSD.

$\mathrm{BR}$ - Basal respiration, SIR - Substrate induced respiration

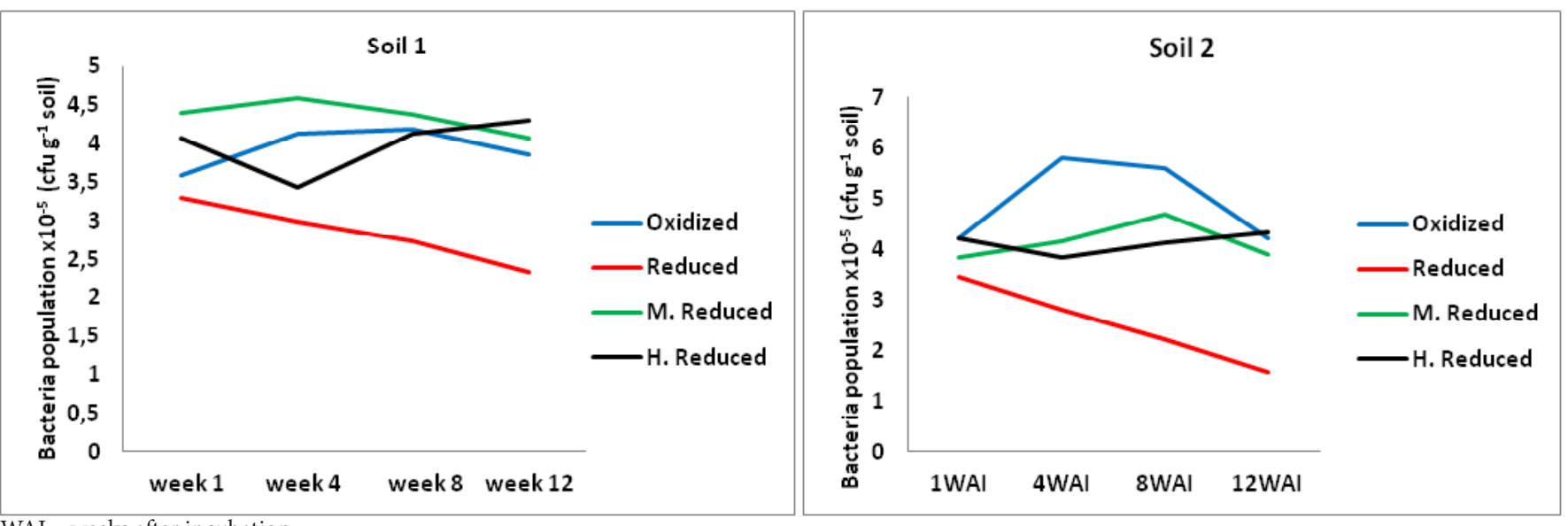

WAI - weeks after incubation

Figure 1: Bacteria population trend from 1WAI to 12 WAI for both soil types

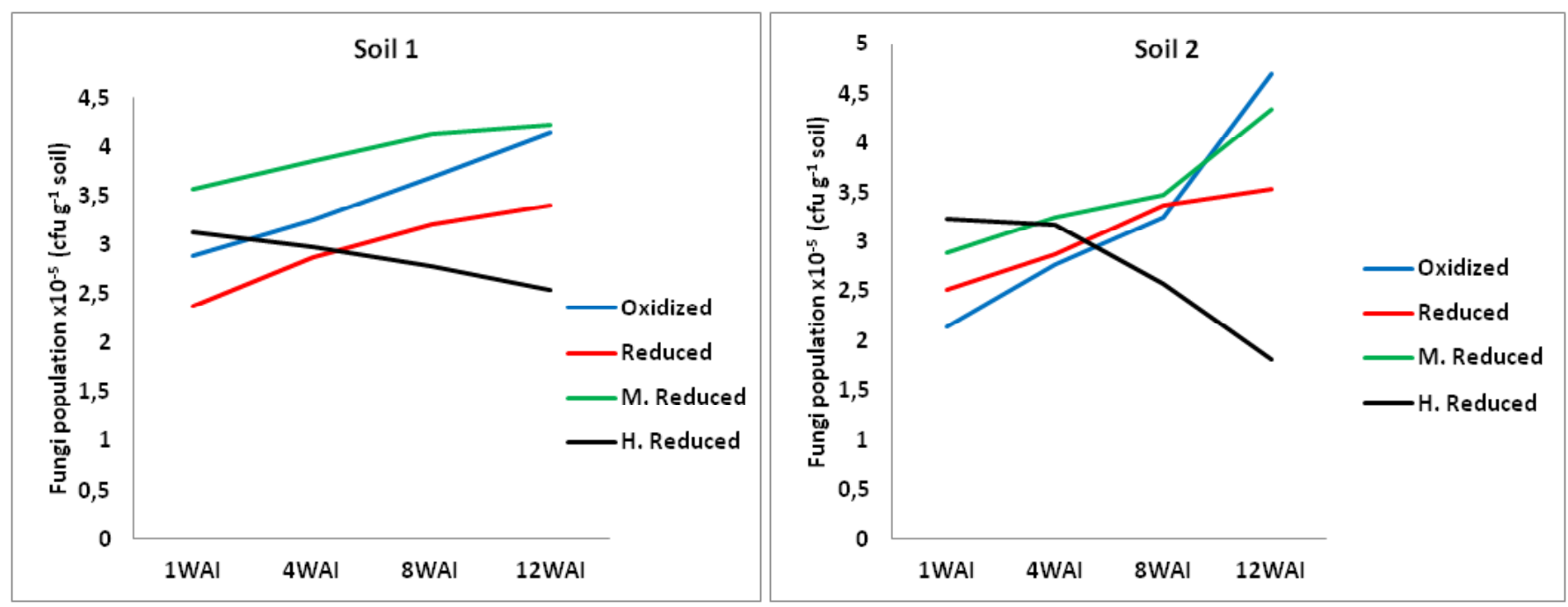

WAI - weeks after incubation

Figure 2: Fungi population trend from 1WAI to 12 WAI for both soil types 
was observed on treatments with the same redox status. Bacteria population increased from 1WAI to 4WAI for most soils that were subjected to moderately reduced and oxidized conditions, the population status was maintained up to 8WAI, but declined at 12WAI. There was a continuous decline in bacteria population from 1WAI to 12WAI under reduced condition. Under highly reduced condition, there was a sharp decline in bacteria population from 1WAI to 4WAI which later picked up from 4WAI to 8WAI and was maintained till 12WAI. Figure 2 shows the fungi population trend from 1WAI to 12WAI for the two sites used for the trial. Black line represents soils that were subjected to highly reduced conditions, red line represents reduced soils, green represents moderately reduced and blue represents oxidized soils. Soils subjected to highly reduced condition were observed to have a continuous decline in fungi population from 1WAI to 12WAI, oxidized and moderately reduced soil had a constant increase in fungi population from 1WAI to 12WAI. The same trend was observed in soil 2. Generally, bacteria population density from 1 WAI to 12 WAI in soil 1 ranged from $2.0 \times 10^{-5}$ to $4.5 \times 10^{-5}$ for all redox potential status, while soil 2 ranged from $1.8 \times 10^{-5}$ to $5.9 \times 10^{-5}$ with moderately reduced soil having the highest in soil 1 and oxidized in soil 2, reduced soil was lowest in both cases. Fungi population density from 1WAI to 12WAI ranged from $2.3 \times 10^{-5}$ to $4.0 \times 10^{-5}$ for soil 1 , while soil 2 ranged from $1.8 \times 10^{-5}$ to $4.6 \times 10^{-5}$ for soil 2 . Highly reduced soils recorded the lowest values while moderately reduced soil had the highest in soil 1 and oxidized soil in soil 2 .

Results from this research showed that fungi population and their survival is best under an oxidation-reduction potential of $100 \mathrm{mV}$ to $>300 \mathrm{mV}$ (moderately reduced and oxidized). Most fungi, particularly those involved in agricultural processes, are known to be obligate aerobic organism and as such require packets of oxygen for survival. This agrees with the statement of Magdoff and Van Es (2012) that under compacted soils bacteria can outdo fungi because of low level of oxygen. Given that reduced and highly reduced conditions have no or low oxygen, they cannot thrive well under such condition. Aerobic bacteria also require oxygen to live and cannot survive under reduced or anoxic conditions, hence, the continuous increase in population from 1WAI to 8WAI under oxidized soils (Fig. 1). According to a research by Hibbing et al. (2010), at the peak of their life cycle, bacteria develop survival mechanism sometimes through the release of toxins into the environment. This coupled with increased competition for nutrient (Amarasekare, 2002), available oxygen (Riedel et al., 2013) and space (Lloyd and Allen, 2015) when population becomes dense can cause microbial population to drop. This could account for the decline in the population observed at 12WAI. When an environment is subjected to waterlogging, oxygen is expelled; this triggers a change in the type of organism that can survive under that condition. In a report by Stamati et al. (2011) on the effect of oxygen on evolution, it is stated that although oxygen is not the only factor that can trigger evolution, however, fluctuation of oxygen can determine the survival and changes of organism in an environment. At the point of low oxygen content in the soil, facultative anaerobe starts taking over the environment and gradually to obligate anaerobes. This phenomenon could be responsible for the sharp decline in population between
1WAI to 4WAI for highly reduced soil which later increased at 8WAI. At 1WAI most of the bacteria are aerobic, but could not survive till 4WAI, because of the anoxic condition of the soil. At 4WAI facultative anaerobe began to take over up to 8WAI, then couple with obligate anaerobes increased the population at 12WAI. This corresponds with an article by Chu (2016) who reported that in the study of marine science greater population of bacteria that are active where reduction process is more pronounced are facultative and obligate anaerobes. However, these obligate anaerobes cannot survive under oxic conditions because oxygen present in air act as excited singlet oxygen which can react with water in their cell to form hydrogen peroxide which is highly reactive and lethal to them because they do not possess any defense for these peroxides. Hence, the continuous increase in bacteria population under oxidized conditions can be attributed to the fact that throughout the trial period, the predominant bacteria were aerobic bacteria. Aerobic organisms, breakdown carbohydrate to form glucose and much energy are released. Under reduced conditions, prevailing organisms can split glucose into just two molecules of pyruvate, however, under oxidized conditions prevailing organisms can breakdown glucose all the way to carbon dioxide which is given off as waste product during cellular respiration. This could account for the high amount of $\mathrm{CO} 2$ that is present in oxidized soils compared with reduced and highly reduced soils.

Comparatively, fungi sustainability under highly reduced soils is not affected by the soil texture, that is the percentage of sand or clay in the soil does not contribute to the overall effect of treatments on fungi. This could be attributed to the fact that most fungi are aerobic in nature and reduced conditions will deprive them of oxygen. The work by Magdoff and Van Es (2012) also supports this claim stating that bacteria can perform better than fungi under low oxygen conditions. However, soil 2 has larger population of fungi than soil 1 for both moderately reduced and oxidized soils. According to an article by the Department of Agriculture of the Republic of South Africa in 2007, soils with more clay content are generally more fertile than those with more sand, this phenomenon according to Malavolta (1980) occurs because of their ability to absorb ion from solution. A report by Hayman (1982) indicated that high soil fertility can support fungi growth and survival as well as benefits mycorrhizal fungi in particular. Bacteria populations under highly reduced and reduced soils follow the same density for soil 1 and 2 . This shows that under these two redox potential conditions, the sand or clay content or texture of the soil does not contribute to the resulting bacteria population density. However, soil 2 has more bacteria density than soil 1 under moderately reduced and oxidized conditions; this can be linked to the fertility and water holding status of individual soils. Works by Garbeva et al. (2004) and Fang et al., (2005) showed that soil type influenced microbial communities' particularly bacterial population. Najmuldeen (2010) also found out that clay loam and silt clay loam had a greater population of bacteria than sandy loam. This could be due to high nutrient and moisture content of soils with more clay content. Heritage et al. (2003) explained that sandy soils cannot retain water and can easily drain out while clay soils have better water and nutrient holding capacity. 


\section{CONCLUSION}

The oxidation-reduction potential of soils determines to a large extent the presence or absence of soil microbes particularly the types that will be prevalent in the soil and their functionality. Based on results from this research, the survival of fungi is best supported under oxidized and moderately reduced soils, but their existence can be negatively affected when soils become highly reduced. Bacteria that are aerobic thrive best under oxidized and moderately reduced soil. However, certain bacteria that are anaerobic in nature thrive best under highly reduced conditions. Given that the trend lines of the two soils used, though similar but not consistent as regards the values, it can be concluded that texture of the soil with oxidation-reduction potential that is greater than $100 \mathrm{mV}$ (moderately reduced and oxidized) contributes to the response of microbes to oxidation-reduction status of soil. However, when oxidation-reduction potential is less than $100 \mathrm{mV}$ (reduced and highly reduced), the effect of soil texture is not significant. However, it is recommended that this trial be repeated on the other soil textures.

\section{REFERENCES}

1. Amarasekare, P. (2002). Interference competition and species coexistence. Proceedings of Biological Sciences, 269, 2541-2550.

2. Brzezinska, M. (2004). Aeration status of soil and enzyme activity. In J. Glinski, G. Josefaciuk \& G. Stahr K. (Eds.), Soil - plant - atmosphere aeration and environmental problems (pp. 55-59). Lublin-Stuttgart: Hohenhein University / Institution of Agrophysics Polish Academy of Science.

3. Chu, J. (2016). Bacterial can survive in marine environments that are almost completely starved of oxygen. Retrieved from https://phys.org/news/2016-12bacteria-survive-marine-environments-starved.html

4. Menta, C. (2012). Soil fauna diversity - Function, soil degradation, biological indices, soil restoration. In G. A. Lameed (Ed.), Biodiversity conservation and utilization in a diverse world (pp 59-94). London: IntechOpen., DOI: 10.5772/51091. Retrieved from: https://www. intechopen.com/books/biodiversity-conservation-andutilization-in-a-diverse-world/soil-fauna-diversityfunction-soil-degradation-biological-indices-soilrestoration

5. Department of Agriculture of the Republic of South Africa (2007). Soil Texture. Soil Potentials. South Africa. Department of Agriculture Press.

6. Dietz, K. J., \& Scheibe R. (2004). Redox regulation: an introduction. Physiology of Plant, 120, 1-3.

7. Falkowski, P. G., Fenchel, T., \& Delong, E. F. (2008), The microbial engines that drive Earth's biogeochemical cycles. Science, 320, 1034-1039.

8. Fang, M., Kremer, R. J., Motavalli, P., \& Davies, G. (2005). Bacterial diversity in trangenic and nontransgenic corn.
Applied and Environmental Microbiology, 71(7), 41324136.

9. Fenchel, T., Blackburn, T. H., \& King, G. M. (2012): Bacterial biogeochemistry: The ecophysiology of mineral cycling. San Diego: Academic Press.

10. Fierer, N., \& Jackson, R. B. (2006). The diversity and biogeography of soil bacterial communities. Proceedings of the National Academy of Science USA, 103, 626-631.

11. FAO (2006). Guidelines for Soil Description $\left(4^{\text {th }}\right.$ Edition). Rome: Food and Agriculture Organization of the United Nations.

12. Garbeva, P., Van Veen, J. A., \& Van Elsas, J. D. (2004). Microbial diversity in soil: selection of microbial populations by plant and soil type and implication of disease suppressiveness. Annual Review of Phytopathology, 42(1), 243-270.

13. Govindjee, \& Krogmann, D. (2004). Discoveries in oxygenic photosynthesis (1727-2003): a perspective. In Govindjee, J. T. Beatty, H. Gest, J. F. Allen (Eds.), Discoveries in Photosynthesis (pp. 63-105). Springer.

14. Harrigan, W. F., \& McCance, M. E. (1976). Laboratory method in food and dairy microbiology. London: Academic Press.

15. Hayman, D. S. (1982). Influence of soil and fertility on activity and survival of vesicular-arbuscular mycorrhizal fungi. Mycorrhiza Symposium, 7(8), 1119-1126.

16. Heritage, J., Evans, E., \& Killington, R. (2003). Microbiology in action. Cambridge University Press.

17. Hibbing, M. E, Fugua, C., Parsek, M. R., \& Peterson, S. B. (2010). Bacterial competition: Surviving and thriving in the microbial jungle. Nature Reviews Microbiology, $8(1), 15-25$.

18. Hines, J., Megonal, P. J., \& Denno, R. F. (2006). Nutrient subsides to belowground microbes impact aboveground food web interactions. Ecology, 87, 1542-1555. Retrieved from https:/doi.org/10.1890/0012-9658(2006)87[1542: NSTBMI]2.0.CO;2

19. Johns, C. (2017). Living soil: The role of microorganism in soil health. Future Direction International. Retrieved from http://www.futuredirection.org.au/publication/ living-soil-role-microoganism-soil-health

20. Kannojia, P., Sharma, R. K., \& Sharma, K. (2019). Climate change and soil dynamics: Effect on soil microbes and fertility of soil. In K. Kumar Choudhary, A. Kumar \& A. K. Singh (Eds.), Climate Change and Agricultural Ecosystem Current Challenges and Adaptation (pp. 4364). Elsevier Inc. Retrieved from http://doi.org/10.1016/ B9780-12-816483-9.00003-7

21. Kimbrough, D. E., Kouame, Y., Moheban, P., \& Springthorpe, S. (2006). The effect of electrolysis and oxidation-reduction potential on microbial survival, growth and disinfection. International Journal of Environmental Pollution, 27, 211-221.

22. Kralova, M., Masscheleyn, P.bH., \& Patrick, W. H. Jr. (1992). Redox potential as an indicator of electron availability for microbial activity and nitrogen transformation in aerobic soils. Microbiology, 147, 328399.

23. Lloyd, D. P., \& Allen, R. J. (2015). Competition for space during biological colonization of a surface. Journal of 
the Royal Society Interface, 12, 20150608. Retrieved from: https://doi.org/10.1098/rsif.2015.0608

24. Lüdemann, H., Arth, I., \& Liesack, W. (2000). Spatial changes in the bacterial community structure along a vertical oxygen gradient in flooded paddy soils cores. Applied Environmental Microbiology, 66, 754-762.

25. Magdoff, F., \& van Es, H. (2000). Building soils for better crops. Burlington, VT, USA: Sustainable Agriculture Network Publications.

26. Malavolta, E. (1980). Elements of mineral nutrition of plants. Sao Paulo, Brazil: Agronômica Ceres.

27. Marino, D., Pucciariello, C., Puppo, A., Frendo, P., \& Jacquot, J.P. (2009). The redox state, a referee of the legume Rhizobia symbiotic game. Advances in Botany Research, 52, 115-151.

28. Najmuldeen, H. (2010). Effects of soil texture on chemical compositions, microbial populations and carbon mineralization in soil. Egyptian Journal of Experimental Biology, 6(1), 59-64.

29. Paul, E. A., \& Clark, F. E. (1989). Soil Microbiology and Biochemistry. San Diego, Academic press.

30. Pett-Ridge, J., \& Firestone, M. K. (2005): Redox fluctuation structures microbial communities in a wet tropical soil. Applied Environmental Microbiology, 71, 6998-7007.

31. Prescott, C. E. (2010). Litter Decomposition: what controls it and how can we alter it to sequester more carbon in forest soils? Biochemistry, 101, 133-149. Retrieved from http://doi.org/10.1007/s10533-0109439-0

32. Rabenhorst, A. C., Hively, W. D., \& James, B. R. (2009). Measurement of soil redox potential. Soil Science Society of America Journal, 73, 668-674.

33. Riedel, T. E., Berelson, W. M., Nealson, K. H., \& Finkel, S. E. (2013). Oxygen consumption rates of bacteria under nutrient limited conditions. Applied and Environmental Microbiology, 79(16), 4921-4931.

34. Stamati, K., Mudera, V., \& Cheema, U. (2011). Evolution of oxygen utilization in multicellular organism and implication for cell signalling in tissue engineering. Journal of Tissue Engineering, 2(1), 2041731411432365. Doi:10.1177/0173141132365.

35. WRBSR(2014). World Reference Base for Soil Resources. World Soil Resources Report, 106. Rome: Food and Agriculture Organization of the United Nations.

\section{Declaration of Interest Statement}

I declare that there is no conflict of interest of any kind between the authors of this manuscript. 


\section{Učinek oksidacijsko-redukcijskega potenciala na talne mikrobe}

\section{IZVLEČEK}

Talni mikrobi so pomembni pri različnih procesih, ki prispevajo k rodovitnosti tal, razpoložljivosti hranil in prehrani rastlin. Delovanje talnih mikroorganizmov je odvisno od okolja, v katerem živijo. Mikrobi so lahko aerobni ali anaerobni, odvisno od njihovih potreb po kisiku. Oksidoredukcijske reakcije so v anoksičnih okoljih pogoste in mikrobi se nanje odzivajo na različne načine. Cilj te raziskave je preučiti vpliv oksidacijsko-redukcijskega potenciala tal na aktivnost talnih mikroorganizmov. Rezultati raziskave so pokazali, da so močno reducirana tla bolj ugodna za razvoj populacij bakterij kot pa populacij gliv. Ugotovljeno je bilo, da so za preživetje gliv najbolj ugodna oksidirana in zmerno reducirana tla, medtem ko lahko močno reducirana tla negativno vplivajo na njihov obstoj. Aerobne bakterije uspevajo najbolje v oksidiranih in zmerno reduciranih tleh. $\mathrm{V}$ teh pogojih so bile izmerjene tudi najvišje vrednosti mikrobnega dihanja v tleh.

Ključne besede: bakterije, glive, populacija, dihanje, redoks potencial 